DOI https://doi.org/10.30525/978-9934-588-79-2-1.14

\title{
ОЦНКА СТРУКТУРНОЇ СКРИТНОСТІ СИГНАЛІВ МОДУЛЯЦІЇ ЦИКЛІЧНИМ ЗСУВОМ КОДУ 3 АДАПТАЦІЄЮ \\ ПО ШВИДКОСТІ ПЕРЕДАВАННЯ ІНФОРМАЦІЇ НА ОСНОВІ ДОСКОНАЛИХ ДВІЙКОВИХ МАТРИЦЬ
}

\author{
Москаленко А. О. \\ кандидат технічних наук, \\ завідувач кафедри програмної інженерї̈ та інформаційних технологій \\ Полтавського інституту бізнесу Закладу вищої освіти \\ «Міжнародний науково-технічний університет \\ імені академіка Юрія Бугая» \\ Ігнатович Д. А. \\ здобувач вищзої освіти \\ Полтавського інституту бізнесу Закладу вищуӧ освіти \\ «Міжнародний науково-технічний університет \\ імені академіка Юрія Бугая» \\ Окара В. В. \\ здобувач вищеої освіти \\ Полтавського інституту бізнесу Закладу вищої освіти \\ «Міжнародний науково-технічний університет \\ імені академіка Юрія Бугая» \\ м. Полтава, Украӥна
}

Для радіосистем спеціального призначення актуальною є задача приховання як самого факту передавання інформації, так і переданої інформації. Одним із параметрів сигналу, що дозволяе змінювати рівень скритності, $є$ його структура.

Під скритністю [1] розуміють здатність протистояти мірам радіотехнічної розвідки: виявленню сигналу і визначенню його структури на основі оцінки ряду його параметрів без врахування можливості розкриття смислу інформації.

Використання для оцінки структурної скритності ймовірності підбору структури сигналу, є недостатнім, оскільки не враховуються алгоритмічні чи інші проблеми, пов'язані з розкриттям події. Крім того, ймовірність підбору структури сигналу, як правило, залежить від характеристик апаратури, які не завжди відомі досліднику і змінюються в процесі вдосконалення. Тому оцінка залежить не лише від 
характеру подій і супутніх обставин, а й від засобів, що використовуються [2].

В роботі [2] запропоновано використовувати в якості одиниці структурної скритності одне двійкове вимірювання (діз). Діз - середня кількість двійкових вимірювань, яку необхідно виконати для рішення задачі розкриття структури сигналу.

У відповідності до [2], структурна скритність сигналів може бути визначена наступним чином:

$$
S=\log _{2} V,
$$

де $S$ - структурна скритність сигналу, $V$ - кількість можливих систем сигналів.

Для оцінки структурної скритності сигналів модуляції циклічним зсувом коду з адаптацією по швидкості передавання інформації на основі досконалих двійкових матриць необхідно розглянути порядок ïх синтезу.

В роботах $[3,4]$ розглянуті питання синтезу сигналів удосконаленої модуляції циклічним зсувом коду з адаптацією по швидкості передавання інформації, запропоновано математичну модель формування сигналів з адаптацією по швидкості передавання інформації на основі досконалих двійкових матриць та алгоритм їх кореляційної обробки, приведені правила формування сигналів адаптивної модуляції циклічним зсувом коду. За результатами аналізу методів формування сигналів з адаптацією по швидкості передавання інформації на основі досконалих двійкових матриць встановлено, що структурна скритність даних сигналів визначається характеристиками досконалих двійкових матриць.

В [5] зазначено, що кількість можливих ортогональних систем сигналів, отриманих на основі досконалих двійкових матриць, визначається:

$$
\begin{aligned}
& V=\frac{3^{n / 2} \times 2^{2^{n+1}-1}}{2^{2 n}}=3^{n / 2} \times 2^{2\left(2^{n}-n-1\right)} \text { при парних } n \mathrm{i} \\
& V=\frac{3^{(n-1) / 2} \times 2^{2^{n+1}}-1}{2^{2 n}}=3^{(n-1) / 2} \times 2^{2\left(2^{n}-n-1\right)} \text { при непарних } n .
\end{aligned}
$$

Прийнявши довжину кодової послідовності за $L$, для даного випадку $n=\frac{\log _{2} L}{2}$.

В табл. 1 приведено обчислені значення кількості можливих систем сигналів для різної довжини послідовності. Для порівняння показано 60 
число М-послідовностей, що використовуються як основа для побудови ряду відомих кодів розширення спектра (Голда, Касамі та ін.).

Таблиця 1

Порівняльний аналіз ансамблевих властивостей сигналів на основі $M$-послідовностей і досконалих двійкових матриць

\begin{tabular}{|c|c|c|c|}
\hline \multicolumn{2}{|c|}{ М-послідовності } & \multicolumn{2}{|c|}{ Сигнали на основі досконалих двійкових матриць } \\
\hline$L$ & $V$ & $L$ & $V$ \\
\hline 15 & 2 & 16 & 12 \\
\hline 63 & 6 & 64 & 768 \\
\hline 255 & 16 & 256 & 37748736 \\
\hline 1023 & 60 & 1024 & 40532396646334464 \\
\hline 4095 & 144 & 4096 & 79228162514361067193543950336 \\
\hline
\end{tabular}

Використовуючи дані, приведені в у табл. 1, побудуємо залежності структурної скритності сигналів від довжини кодової послідовності для сигналів модуляції циклічним зсувом коду з адаптацією по швидкості передавання інформації на основі досконалих двійкових матриць і сигналів $M$-ічної ортогональної модуляції (рис. 1).

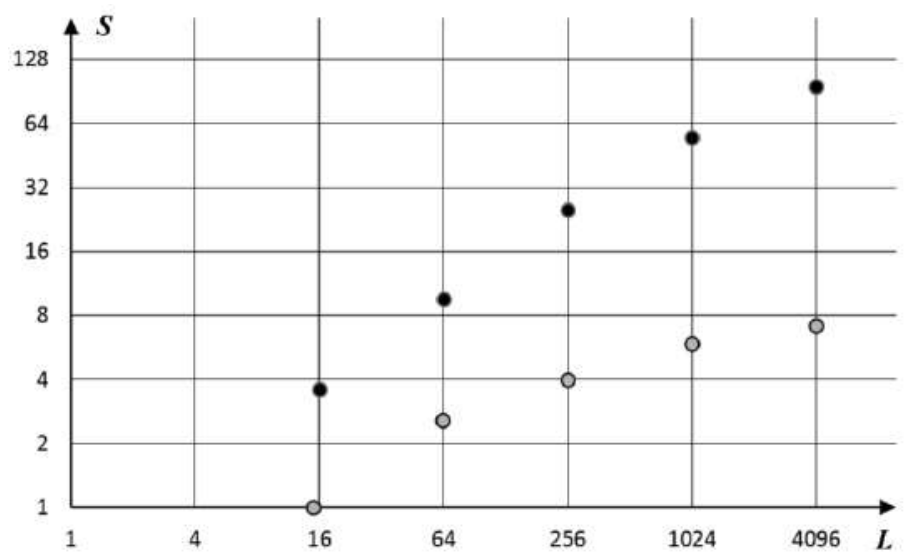

Рис. 1. Залежність структурної скритності від довжини кодової послідовності сигналів модуляції циклічним зсувом коду 3 адаптацією по швидкості передавання інформації на основі досконалих двійкових матриць і $M$-послідовностей 
Як видно із рис. 1, структурна скритність сигналів модуляції циклічним зсувом коду з адаптацією по швидкості передавання інформації на основі досконалих двійкових матриць більша за структурну скритність $M$-послідовностей, до того ж, при збільшенні довжини кодової послідовності $(L)$, структурна скритність сигналів модуляції циклічним зсувом коду з адаптацією по швидкості передавання інформації на основі досконалих двійкових матриць зростає стрімкіше.

Таким чином, використання сигналів модуляції циклічним зсувом коду з адаптацією по швидкості передавання інформації на основі досконалих двійкових матриць замість $M$-послідовностей дозволить підвищити структурну скритність радіосистем спеціального призначення. Наприклад, при довжина кодової послідовності, що використовується для розширення спектра, 256 біт, структурна скритність сигналів модуляції циклічним зсувом коду 3 адаптацією по швидкості передавання інформації на основі досконалих двійкових матриць буде більша за структурну скритність сигналів на основі $M$-послідовностей в $25.17 / 4 \approx 6.29$ разів, причому виграш має тенденцію збільшуватись при збільшенні довжини кодової послідовності.

\section{Література:}

1. Тузов Г.И., Сивов В.А., Прытков В.И. и др. Помехозащищенность радиосистем со сложными сигналами. М.: Радио и связь, 1985. $264 \mathrm{c}$.

2. Каневский 3.М., Литвиненко В.П. Теория скрытности. Воронеж: ВГУ, 1991. 144 с.

3. Москаленко А.О., Сокол Г.В., Глуховець Ю.В., Варич В.В. Математична модель формування сигналів з адаптацією по швидкості передавання інформації на основі досконалих двійкових матриць. Системи управління, навігації та зв'язку. 2020. № 1(59). С. 147-150.

4. Москаленко А.О., Сокол Г.В., Рвачова Н.В., Буряк Т.В., Глуховець Ю.В., Варич В.В. Перешкодостійкість сигналів модуляції циклічним зсувом коду з адаптацією по швидкості передачі інформації. Системи управління, навігації та зв'язку. 2018. № 3(49). С. 175-180.

5. Гепко И.А. Синтез совершенных двоичных решеток. Радиоэлектроника (Изв. высш. учебн. заведений). 1998. Т.41. № 6. С. 13-21. 